\title{
First record of Melanoides tuberculatus (Müller, 1774) and Biomphalaria tenagophila (d'Orbigny, 1835) on Ilha Grande, Rio de Janeiro, Brazil
}

\author{
Sonia Barbosa dos Santos ${ }^{1,2}$, Igor Christo Miyahira ${ }^{1}$ \& Luiz Eduardo Macedo de Lacerda ${ }^{1}$ \\ Biota Neotropica $v 7(n 3)$ \\ http://www.biotaneotropica.org.br/v7n3/pt/abstract?short-communication+bn01307032007
}

Data Received 24/11/06

Revised 24/07/07

Published 06/09/07

\begin{abstract}
${ }^{1}$ Laboratório de Malacologia, Instituto de Biologia Roberto Alcantara Gomes,
Universidade do Estado do Rio de Janeiro, Rua São Francisco Xavier 524 PHLC sala 525-2, CEP 20550-900, Maracanã, Rio de Janeiro,RJ, Brasil, gundlachia@yahoo.com.br,

${ }^{2}$ Corresponding author: Sonia Barbosados Santos, e-mail: sbsantos@uerj.br,www.uerj.br
\end{abstract}

\begin{abstract}
Santos, S.B., Miyahira, I.C. \& Lacerda, L.E.M. First record of Melanoides tuberculatus (Müller, 1774) and Biomphalaria tenagophila (d'Orbigny, 1835) on Ilha Grande, Rio de Janeiro, Brazil. Biota Neotrop. Sep/ Dez 2007 vol. 7, no. 3 http://www.biotaneotropica.org.br/v7n3/pt/abstract?short-communication+bn01307032007. ISSN 1676-0603.

Small populations of Melanoides tuberculatus (Müller, 1774) and Biomphalaria tenagophila (d’Orbigny, 1835), were found at Vila do Abraão, being the first record of these species to Ilha Grande, Angra dos Reis, Rio de Janeiro. They were probably introduced after 2004, perhaps following release from aquaria. The possible spread of these species to other freshwater habitats in the island, their effects on native snails and links with public health are discussed. The record of $M$. tuberculatus appears to be the first for a Brazilian insular area. The recent introduction of these species offers a remarkable opportunity to monitor introduced species and to understand the invasion process in an insular stream in southeastern Brazil.
\end{abstract}

Keywords: biological invasion, new records, freshwater snails, Mollusca, southeastern Brazil.

\section{Resumo}

Santos, S.B., Miyahira, I.C. \& Lacerda, L.E.M. Primeiro registro de Melanoides tuberculatus (Müller, 1774) e Biomphalaria tenagophila (d’Orbigny, 1835) para a Ilha Grande, Rio de Janeiro, Brasil. Biota Neotrop. Sep/ Dez 2007 vol. 7, no. 3 http://www.biotaneotropica.org.br/v7n3/pt/abstract?short-communication+bn01307032007. ISSN 1676-0603.

Pequenas populações de Melanoides tuberculatus (Müller, 1774) e de Biomphalaria tenagophila (d’Orbigny, 1835) foram encontradas na Vila do Abraão, sendo este o primeiro registro dessas espécies para a Ilha Grande, Angra dos Reis, Rio de Janeiro. A introdução provavelmente ocorreu após 2004, como consequiência do despejo de água de aquário. A possível dispersão destas espécies para outros corpos d’água, efeitos sobre as espécies nativas e consequiências para saúde pública são tópicos discutidos. Em relação a $M$. tuberculatus, este é o primeiro registro para uma área insular do Brasil. A introdução recente destas espécies oferece uma oportunidade única para o monitoramento de espécies introduzidas e para uma melhor compreensão do processo de invasão, especialmente de M. tuberculatus, em córrego insular do sudeste do Brasil.

Palavras-chave: invasão biológica, novos registros, gastrópodes límnicos, Mollusca, Brasil. 


\section{Introduction}

This article describes the first record of the non-native species Melanoides tuberculatus (Müller, 1774) and Biomphalaria tenagophila (d'Orbigny, 1835) for Ilha Grande, Rio de Janeiro State, Brazil $\left(23^{\circ} 05^{\prime}, 23^{\circ} 15^{\prime} \mathrm{S}\right.$ and $44^{\circ} 06^{\prime}$ and $\left.44^{\circ} 23^{\prime} \mathrm{W}\right)$, an insular area southeastern Brazil (Figure 1), and discusses the possible implications to environment and to public health.

Ilha Grande has important protected remnants of tropical forests at highlands and disturbed habitats at lowlands, being included in the Brazilian Atlantic Rainforest hotspot (Myers et al. 2000). The invertebrate fauna, including freshwater mollusks, is poorly known, with only three publications dealing with it (Haas 1953, Santos et al.
1999, Thiengo et al. 2004a), reporting Anysancylus obliquus Broderip \& Sowerby 1832, a misidentification according Santos et al. (1999); Pisidium globosus Clessin, 1822, in fact, Pisidium punctiferum (Guppy 1867) according M.C.D. Mansur (personal information), Antillorbis nordestensis (Lucena 1954), Ferrissia sp., Gundlachia sp. and Gundlachia ticaga (Marcus \& Marcus 1962).

According Richardson et al (2000) and Colautti \& MacIsaac (2004) much confusion exist concerning terms and concepts associated with invasion ecology, addressed by authors preferences in the use of existing terminology. So, in this article, we are using the word introduced meaning a species transported across a geographical barrier through human agency (Richardson et al. 2000) or through zoochory (Green \& Figuerola 2005). Biological invaders, that is,

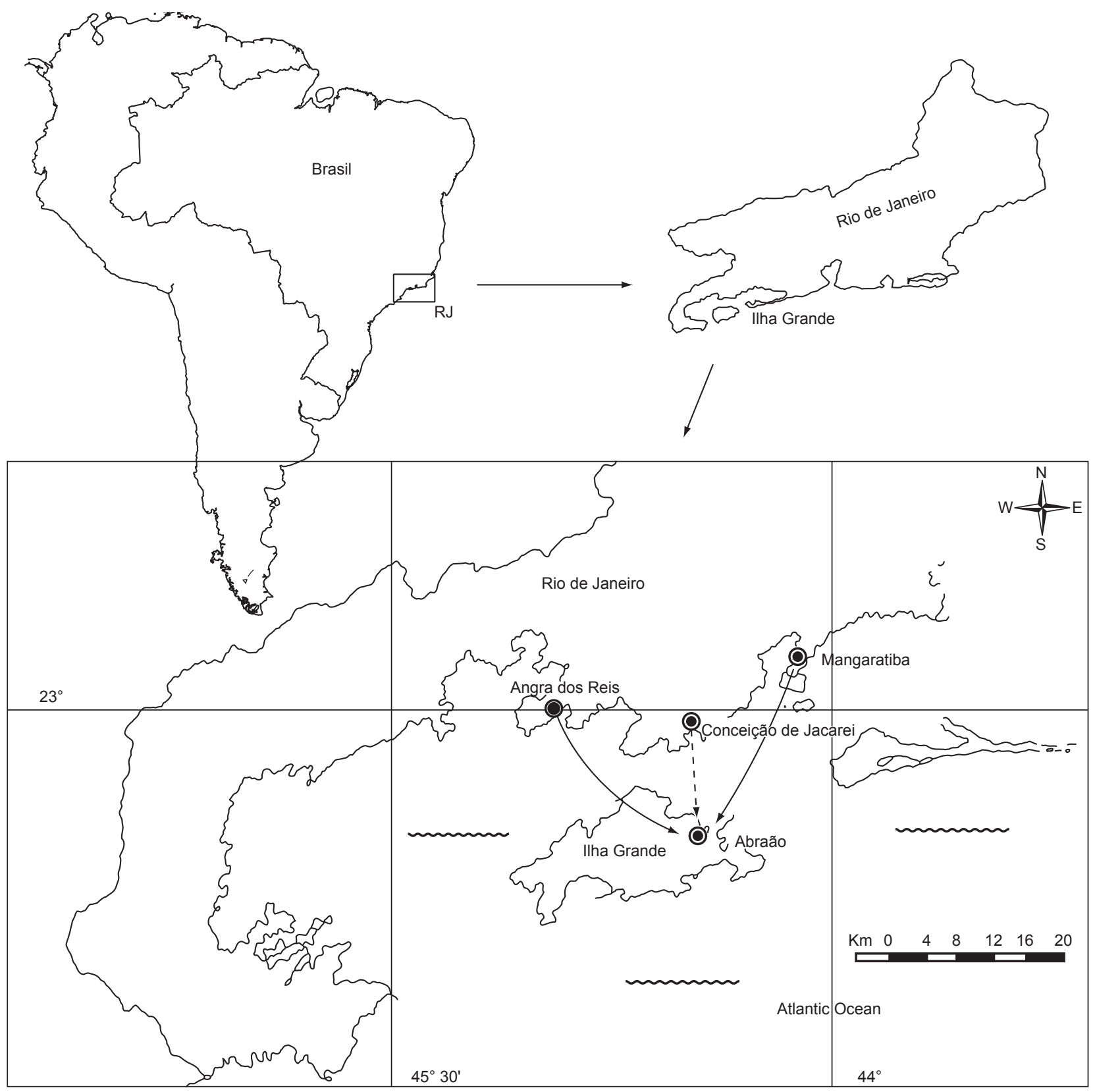

Figure 1. Map of Ilha Grande, which is located in the south of Rio de Janeiro, showing the study site. Solid black arrows indicate the probable routes of introduction. The dashed arrow indicates an alternative route.

Figura 1. Mapa da Ilha Grande, localizada no sul do Estado do Rio de Janeiro, mostrando a área de estudo. As setas cheias indicam as provaveis rotas de introdução. A seta tracejada indica uma rota alternativa. 
nonindigenous species both widespread and locally dominant (stage $\mathrm{V}$ of Colautti \& MacIsaac 2004), and their effects on native species are one of main causes of decreasing biodiversity, in addition to loss or modification of native habitats (Mack et al. 2000, Cowie 2001). Modified and destroyed habitats on Ilha Grande, especially around coastal villages, provided suitable habitats not only for non-native terrestrial snails such as Bradybaena similaris (Férussac, 1821) and Achatina fulica Bowdich 1922, first reported by Santos et al. (2002) but also for freshwater snails.

Melanoides tuberculatus, an Afro-Asiatic thiarid (Pilsbry \& Bequaert 1927), was introduced to Latin America in the late 1960s and is now widespread in almost all regions (Brown 1994; Fernandez et al. 2003). The first record of this species in Brazil was in 1967, in Santos, state of São Paulo (Vaz et al. 1986), probably introduced by the aquarium trade. Biomphalaria tenagophila is one of the natural vectors of Schistosoma mansoni Sambon, 1907 and it is widely distributed in Rio de Janeiro (Thiengo et al. 2001, 2002a, b, 2004a, b) but was not registered in Ilha Grande till now.

According to Cowie $(1998,2001)$, based on studies of the effects of invasive snails in the Pacific, insular ecosystems are under several threats. Similar studies in Brazil pointed out evidences that Melanoides tuberculatus are able to rapidly colonize modified areas limiting (Pointier, 1993) or even excluding native species of Planorbidae such as B. glabrata (Say, 1818), B. straminea (Dunker, 1848) and B. tenagophila (Freitas et al. 1987, Guimarães et al. 2001, Giovanelli 2005); Thiaridae such as Aylacostoma tenuilabris (Reeve, 1860) (Fernandez et al. 2001) and Ampullariidae such as Pomacea lineata (Spix, 1827) (Fernandez et al. 2003).

On August 19 and October 28, 2005, we surveyed four streams that come down the mountains and reach the coast flowing through Vila do Abraão. Water depth varies from 5 to $30 \mathrm{~cm}$; width from 1.5 to $2.5 \mathrm{~m}$; the substrate is made up of silt, sand, gravel and organic debris as well all kinds of garbage. Two collecting methods were used, in order to assess the most complete snail inventory and for qualitative and quantitative studies (in preparation). Three people searched for snails for 15 minutes in the stream substrate, with a long handled metalic scoop. They also searched for snails by eye for 15 minutes in other possible habitats, as under garbage, stones, decayed leaves and sticks.

Live snails were transported and kept in the laboratory for biological observations, taxonomic identification and parasitological studies. Samples were deposited in the Malacological Collection of the Universidade do Estado do Rio de Janeiro (B. tenagophila: Col. Mol. UERJ 4226 and 4227; M. tuberculatus: Col. Mol. UERJ 4235 and 4236).

\section{Results and Discussion}

During the course of surveys undertaken since 1995 to record the composition and distribution of freshwater snails on Ilha Grande, we found, in August and October 2005, small populations of Melanoides tuberculatus and Biomphalaria tenagophila in one of the four streams that flows through Vila do Abraão, the principal village of Ilha Grande

The thiarids were found only downstream, in an area under tidal influence, beginning $20 \mathrm{~m}$ inland from the stream mouth and extending along approximately $130 \mathrm{~m}$ of the stream that lacked riparian vegetation and where the margins are altered by a cemented stone wall that provides many suitable refuges for the snails. The planorbids were found in another site, with riparian vegetation, $50 \mathrm{~m}$ upstream from the first site. Only one live specimen of B. tenagophila was found at the site where $M$. tuberculatus was found, on a decayed palm leaf; it may have been carried downstream.
Eighty six specimens of $M$. tuberculatus were collected, 65 in August and 21 in October. We found 22 specimens of B. tenagophila in October but none in August. The small number of specimens of both species and the restricted area where they occurred suggest us that the introduction was very recent (Mack et al. 2000), especially because Thiengo et al. (2004a) had recently searched Vila Abraão's streams, from March 2000 to May 2002 and did not find these species.

Although birds play an important role on the spreading of freshwater snails because they can carry snails on feet or plumage, or even through the alimentary canal (Madsen \& Franzen 1989, Green \& Figuerola 2005), we think the most likely mechanism of introduction is aquarium release, as suggested by Corrêa et al. (1980) regarding the spreading of several freshwater snails in Brazil, by Vaz et al. (1986) and Thiengo et al. (2003) regarding $M$ tuberculatus in Brazil and, by Duggan (2002) regarding the introduction of M. tuberculatus to New Zealand. In support of this hypothesis we can mention that we saw an unused aquarium at the backyard of a house near the site where we found B. tenagophila. This new record seems to be the first in an insular area in Brazil.

Vila do Abraão is the most populous village and the principal port of entry into Ilha Grande, with intense and increasing tourism. Many kinds of ships connect Ilha Grande with the continental mainland, through the ports of Angra dos Reis and Mangaratiba, the two most likely possible routes of introduction. Of probable less importance is Conceição de Jacareí city (Figure 1), that is not a regular tourist or commercial route. Both species occurs in adjacent continental areas of the state of Rio de Janeiro including Mangaratiba (Thiengo et al. 2001) and Angra dos Reis (Thiengo et al. 2004a) municipalities.

We are now monitoring these populations bimonthly to observe its spread, effects on the native fauna and possible competition among these two species. According to previous literature on invasive behavior of $M$. tuberculatus, it is quite probable the spreading of this species by two reasons: the first one, because of its biology, especially its viviparity, iteroparity, parthenogenesis, and high survival rates of juveniles; the second one, the proximity of the others water bodies. If $M$. tuberculatus spreads to other water bodies, it could be harmful to Ilha Grande's native fauna. Regarding B. tenagophila, if it could be able to establish on Ilha Grande, this species could be a potential risk to public health, as cases of schistosomiasis have been identified at Mangaratiba (Thiengo et al. 2001) and Angra dos Reis (Thiengo et al. 2004a).

The apparently very recent introduction of these species offers a remarkable opportunity to monitor invasion behavior of introduced species, and to better understand invasive process, especially of M. tuberculatus, in an insular stream in southeastern Brazil.

\section{Acknowledgments}

We thank the Laboratory of Malacology student team, Gleisse Kelly M. Nunes, Amilcar B. Barbosa, Tiago A. Viana and Francielle C. Fonseca who helped with field work. To CEADS/UERJ (Centro de Estudos Ambientais e Desenvolvimento Sustentável da Universidade do Estado do Rio de Janeiro) for providing facilities; to Dr. Silvana Thiengo (Instituto Oswaldo Cruz) and also to the two anonymous reviewers that provided valuable comments. Sonia B. Santos had financial support from $\mathrm{CNPq}$ (Conselho Nacional de Desenvolvimento Científico e Tecnológico); Igor C. Miyahira was supported by a scholarship from CNPq and Luiz E. M. de Lacerda by a scholarship from UERJ.

\section{References}

BROWN, D.S. 1994. Freshwater snails of Africa and their medical importance. Taylor and Francis, London. 
COLAUTTI, R. I \& MacISAAC, H.J. 2004. A neutral terminology to define "invasive" species. Diversity Distrib. 10:135-141.

CORRÊA, L.L., CORRÊA, M.O.A., VAZ, J.F., SILVA, M.I.P.G., SILVA, R.M. \& YAMANAKA, M.T. 1980. Importância das plantas ornamentais dos aquários como veículos de propagação de vetores de Schistosoma mansoni. Rev. Inst. Adolfo Lutz 40(2):89-96.

COWIE, R.H. 1998. Patterns of introduction of non-indigenous non-marine snails and slugs in the Hawaiian Islands. Biodiv. Conserv. 7:349-368.

COWIE, R.H. 2001. Invertebrate invasions on Pacific Islands and the replacement of unique native faunas: a synthesis of the land and freshwater snails. Biol. Invasions 3:119-136.

DUGGAN, I.C. 2002. First record of a wild population of the tropical snail Melanoides tuberculata in New Zealand natural waters. New Zeal. J. Mar. Fresh. Res. 36:825-829.

FERNANDEZ, M.A., THIENGO, S.C. \& BOAVENTURA, M.F. 2001. Gastrópodes límnicos do Campus de Manguinhos, Fundação Oswaldo Cruz. Rev. Soc. Bras. Med. Trop. 34:279-282.

FERNANDEZ, M.A., THIENGO, S.C. \& SIMONE, L.R.L. 2003. Distribution of the introduced freshwater snail Melanoides tuberculatus (Gastropoda: Thiaridae) in Brazil. Nautilus 117:78-82.

FREITAS, J.R., BEDÊ, L.C., MARCO JR., P., ROCHA, L.A. \& SANTOS, M.B.L. 1987. Population dynamics of aquatic snails in Pampulha reservoir. Mem. Inst. Oswaldo Cruz 82 (Suppl. IV):299-305.

GIOVANELI, A., SILVA, C.L.P.A.C., LEAL, G.B.E. \& BAPTISTA, D.F. 2005. Habitat preference of freshwater snails in relation to environmental factors and the presence of the competitor snail Melanoides tuberculatus (Müller, 1774). Mem. Inst. Oswaldo Cruz 100:169-176.

GREEN, A. J. \& FIGUEROLA, J. 2005. Recent advances in the study of long-distance dispersal of aquatic invertebrates via birds. Diversity Distrib. 11:149-156.

GUIMARÃES, C.T., SOUZA, C.P. \& SOARES, D.M. 2001. Possible competitive displacement of planorbids by Melanoides tuberculata in Minas Gerais, Brazil. Mem. Inst. Oswaldo Cruz 96 (Suppl.):173-176.

HAAS, F. 1953. Mollusks from Ilha Grande, Rio de Janeiro, Brazil. Fieldiana, Zool. 34:203-209.

MACK, R.N., SIMBERLOFF, D., LONSDALE, W.M., EVANS, H., CLOUT, M. \& BAZZAZ, F. 2000. Biotic invasions: Causes, epidemiology, global consequences and control. Issues in Ecology 5:2-19.

MADSEN, H. \& FRANDSEN, F. 1989. The spread of freshwater snails including those of medical and veterinary importance. Acta Trop. 46:139-146.

MYERS, N., MITTERMEIER, R.A., MITTERMEIER, C.G., FONSECA, G.A.B. \& KENT, J. 2000. Biodiversity hotspots for conservation priorities. Nature 403:853-858.
PILSBRY, H.A. \& BEQUAERT, J. 1927. Aquatic Mollusks of Belgian Congo. Bull Am. Mus. Nat. Hist. 53:59-602.

POINTIER, J.P. 1993. The introduction of Melanoides tuberculata (Mollusca: Thiaridae) to the island of Saint Lucia (West Indies) and its role in the decline of Biomphalaria glabrata, the snail intermediate host of Schistosoma mansoni. Acta Trop. 54:13-18

RICHARDSON, D.M., PYSEK, P., REJMÁNEK, M., BARBOUR, M.G., PANETTA, F.D. \& WEST, C.J. 2000. Naturalization and invasion of alien plants: concepts and definitions. Diversity Distrib. 6:93-107.

SANTOS, S.B., MONTEIRO, D.P., FERNANDEZ, M.A. \& THIENGO, S.C. 1999. Primeiro registro de Antillorbis nordestensis (Lucena) (Mollusca, Gastropoda, Planorbidae) para a Ilha Grande, Angra dos Reis, Rio de Janeiro. Revta bras. Zool. 16 (Suppl. 2):257-259.

SANTOS, S.B., MONTEIRO, D.P. \& THIENGO, S.C. 2002. Achatina fulica (Mollusca, Achatinidae) na Ilha Grande, Angra dos Reis, Rio de Janeiro: implicações para a saúde ambiental. Biociências 10:159-162.

THIENGO, S.C., FERNANDEZ, M.A., BOAVENTURA, M.F., GRAULT, C.E., SILVA, H.F.R., MATTOS, A.C. \& SANTOS, S.B. 2001. Freshwater snails and schistosomiasis mansoni in the state of Rio de Janeiro, Brazil: I - Metropolitan mesoregion. Mem. Inst. Oswaldo Cruz 96 (Suppl.):177-184.

THIENGO, S.C., FERNANDEZ, M.A., SANTOS, S.B., BOAVENTURA, M.F. \& MATTOS, A.C. 2002a. Freshwater snails and schistosomiasis mansoni in the state of Rio de Janeiro, Brazil: II - Centro Fluminense mesoregion. Mem. Inst. Oswaldo Cruz 97:621-626.

THIENGO, S.C., FERNANDEZ, M.A., BOAVENTURA, M.F., MAGALHÃES, M.G. \& SANTOS, S.B. 2002b. Freshwater snails and schistosomiasis mansoni in the state of Rio de Janeiro, Brazil: III - Baixadas mesoregion. Mem. Inst. Oswaldo Cruz 97(Suppl. 1):43-46.

THIENGO, S.C., MATTOS, A.C., BOAVENTURA, M.F. \& FERNANDEZ, M.A. 2004a. Freshwater snails and schistosomiasis mansoni in the state of Rio de Janeiro, Brazil: IV - Sul Fluminense mesoregion. Mem. Inst. Oswaldo Cruz 99:275-280.

THIENGO, S.C., MATTOS, A.C., BOAVENTURA, M.F., LOUREIRO, M.S., SANTOS, S.B. \& FERNANDEZ, M.A. 2004b. Freshwater snails and schistosomiasis mansoni in the state of Rio de Janeiro, Brazil: $\mathrm{V}$ - Norte Fluminense mesoregion. Mem. Inst. Oswaldo Cruz 99 (Suppl.1):99-103.

VAZ, J.F., TELES, H.M.S., CORREA, M.A. \& LEITE, S.P.S. 1986. Ocorrência no Brasil de Thiara (Melanoides) tuberculata (O.F. Muller, 1774) (Gastropoda, Prosobranchia), primeiro hospedeiro intermediário de Clonorchis sinensis (Cobbold, 1875) (Trematoda, Plathyhelmintes). Rev. Saúde Pública 20:318-322. 